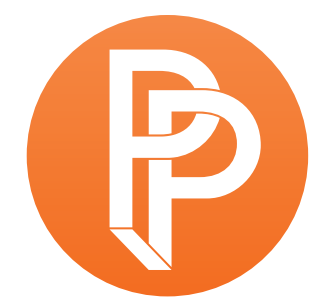

PERFORMANCE

PHILOSOPHY

\title{
THIS KINETIC WORLD: RETHINKING THE GRID (NEO-BAROQUE CALLS)
}

\author{
LARA D. NIELSEN IE UNIVERSITY-MADRID
}

Distance is not a safety zone but a field of tension.

Theodor Adorno, Minima Moralia $(2005,127)$

Changing course and moving to Spain got me thinking about the grid again. I thought l'd left it, but I was heading right back into it. Truth is, there's no getting out of it. Some things are for real.

It is in Spain that the city grid (la cuadrícula) renewed its license, so to speak, on modernity. Ruins of $2^{\text {nd }}$ century BCE cities like Baelo Claudia, for instance, a Roman municipality doing trade with the Maghreb, imprint the grid's heterogeneous and syncretic leave (complete with basilica, forum, amphitheatre, temples of Juno, Minerva and the Egyptian Isis). The Alhambra in Granada was built over Roman ruins, its fine interior courts and muqarnas (geometrical, or honeycomb vaulting) the signature of Moorish architecture and design. On the exterior, the grand scale of its organic layout piles quadrangular additions across the mountain ridge in a manner reminiscent of ramshackle medieval cities throughout the Mediterranean, with passages going this way and that. Thus it is noteworthy that among the first known cuadrículas implemented in early modern Spain was a military encampment built in Santa Fe de Granada, in 1491, by Catholic armies forcing out the Muslim Emirate of Granada in the Reconquista. For the Romans as for the Emirates and the Spanish, city grid regimes are conditioned by contact with its "others." 
For some 200 years, Granada was the last Emirate standing in Iberia. The last of the Nasrid Sultans of Granada (Abu `Abdallah Muhammad XII, or King Boabdil in Spanish) fell to the artillery and canons of the Catholic Monarchs, King Ferdinand II of Aragon and Queen Isabella I of Castile, on January 2, 1492. Christopher Columbus attended that elaborate surrender procession, and four months later it is again in Santa Fe de Granada that Los Reyes Católicos Ferdinand and Isabella anointed Columbus as Admiral of the Ocean Sea (among other titles), and a tenth of whatever riches were to be had in the New World. Consulting with the authorities of their time (sailors, philosophers, astrologers) Los Reyes Católicos made their move. Applying Reconquista logics and technologies to the new world, Spanish urban development established the city grid as a colonial planning rubric, both thing and idea, for new world administrations.

Navigating by constellations of stars, the grid hopscotches seas. The urban grid was implemented across the Spanish Americas, beginning with the first colonial grid city in Santo Domingo, 1502 (Hispaniola/ Dominican Republic). More quickly followed: Cartagena, 1522 (Colombia); Ciudad de los Reyes/Lima, 1535 (Peru); San Juan de la Frontera, 1562 (Argentina); Mexico City, 1585 (Mexico). Returning the city grid regime back to Spain, Madrid was chosen to be the capital city in 1561 . Construction of the Plaza Mayor began in 1617, establishing a centralized grid for the Spanish seat of power. This is the transcultural story of mimicry and man (Bhabha 1984). While no one city is alike, the city itself is a medium (Lefebvre 2007; Kittler 2013).

Across Mediterranean, Atlantic, Caribbean, and Pacific trading cities, the grid's metamorphoses are diverse (Focillon 1989). As at least one medievalist remarks, "Form is too promiscuous to remain faithful to its authors intentions" (Powell 2012, 15). It bears remembering that in geometry, there is no one kind of grid; in fact, there are too many kinds to meaningfully detail. At its most elementary, the Regular grid is made up of tessellated Euclidean bricks, i.e., the meeting of four squares at every vertex. A Cartesian grid produces unit squares and cubes. Rectilinear grids are parallelepipeds made up of rhomboids. Curvilinear grids make curved cuboids radiating out from a center, as in the ancient proscenium stages at Epidaurus; and in the three-dimensional model of the evil Empire's Death Star, in Star Wars. Irregular grids too require a theory for their connectivity, or network flow. Geometry is diverse.

Whatever form the grid takes, tensions between calculation and imagination define it (Zielinksi $2006,10)$. Generally, the grid presents a mode of data formatting and data visualization (design), using points, lines, and curves to communicate ideas, patterns, systems, and complexities. Without wishing to establish a point of origin for the grid, and without trying to establish a linear progression for grid media, I do want to notice things that rhyme with the grid. Dating from the Mesopotamian millennia, for example, mosaics made of patterned assemblages of materials (stone, glass, shells) dot Mycenean, Greek, Roman, Byzantine, Islamic, and Venetian tilings, in pictorial and abstract iterations. ${ }^{1}$

Whether viewed as a spatial index, or as a network, when I think about the grid what I want to focus on is its sheer variability, in tandem with its key operating dynamic: that tension between calculability and imagination. To get closer to what I mean about that tension, you could say that 
the grid's system design presents as a geography of geometricized reason that is matched by the no less impactful circuits of migrant flows and marronage flights (Césaire 1955; Roberts 2015). What Deleuze and Guattari call "fugitives from geometricization" are nothing less than lines that escape geometry (Fer 2004, 55-56; Deleuze and Guattari 1988, 499). Another way of saying it is that grids always also double as network sabotage. The mathematical correlate is Menger's Theorem, the optimization principle of connectivity that holds the key to breaking networks: if you can identify the rule that makes a grid cohere, you can disrupt it. ${ }^{2}$ The grid's reason warps and woofs, if you can master it.

Yet it's still hard to shake the enduring fiction of the grid's neutrality, on the one hand; or its "totalitarianism," on the other (Siegert 2015, 98). I am wary of kingmen's games in the former interpretation, and sympathetic to the concerns of the latter. For Latin Americanists like Walter Mignolo (1995), for example, Spanish grids enact violence, a cartographic "emptying" of indigenous histories in the Americas. A medium and a mechanism for such clearings, the cartographic grid stalls and installs coloniality, but not without shady deals, getaways, stowaways, and storytelling. Meanwhile, Mercator maps simultaneously project latitudes and longitudes pointing eternally North South East and West off the sheer surface of the map's paper, as if the earth were flat; because it is not, such maps bluntly disfigure and deform space, and cannot measure the world as it is, even if Mercator maps continue to influence the imagination. The medium is the message.

While cultural conceptions of space are diverse, historians of cartography show that cartographic power in the Americas is a symptom of nationalizing administrations in search of pinning down "fugitive" (unofficial, unacknowledged, illegitimate, illegible, and resistant) landscapes. ${ }^{3}$ As such, maps posit historically located and subjective forms of knowledge, rather than pure science; as Raymond Craib observes, "Maps are active, creative, and constitutive. More bluntly, they are implicated in creating the reality that they presume to reveal" (Craib 2000, 13). Revisiting the grid cannot but reenact the doubling of thing and idea, in all its fantasias.

Where the grid presents as pliable material and tool, its plasticity is repeatable and adaptable, corruptible. If the grid expresses geometry in spatial organization, material dynamics, and visual fields (a drawing, a map), it also harbors haphazard, mutinous, and renegade affordances. Following the logic of the line, the grid blurs the line. The grid oscillates between mimesis and methexis, inscribing ambivalence, and obsession. I see it everywhere, and I know I'm not alone. ${ }^{4}$

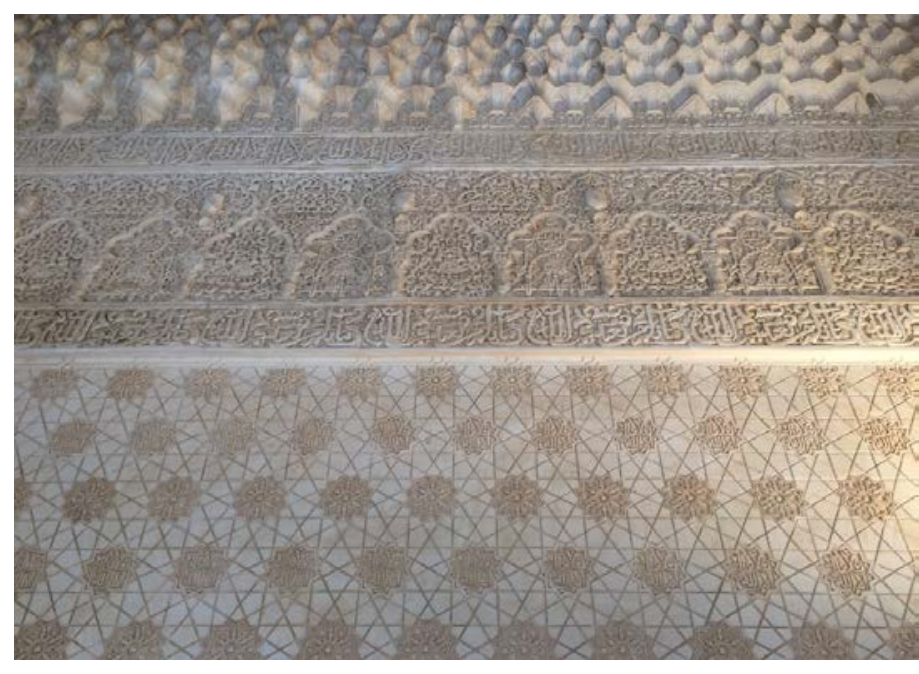

Tiling, La Alhambra, Granada. Photograph by Lara D. Nielsen. 
In Andalucía, where I live, the visual structure of abstract ornamentation in tesselated grid tiling summons the dynamic polyvocalities of geometric grids. Intersecting circles representing the Quranic six days of creation generate points and lines that build the Seal of Solomon. Patterns of hexagons and stars express original and eternal order, both spiritual and material. In Daud Sutton's description, "Islamic design can be thought of as a form of visual music; the repetition and rhythm of its motifs establish an inner sense of balance and act as a visual extension of the invocatory remembrance of the Divine" $(2007,50)$.

Music theorists say John Coltrane heard it, too, in "A Love Supreme," making the Coltrane Circle of Fifths as much music theory as it is devotional work (see Mwamba 2017; Hollander 2017). As a child, I had a coloring book of this kind of geometric design, and its rhythms stick with me to this day. Like tessellated tiling in Andalusian ceramics, which warp and weft the sacred (the singular, the exceptional) and the profane (the plural), honeycomb grids offer undulating patterns and permutations, again in hexagons. What I hear is that the universe is both capaciously diverse, and, in a state of flux. It's not clear who or what is in charge, beyond the dynamics of continuity and change.

So say the physicists. Long story short, Einstein's 1915 theory of relativity advances the idea that matter (energy) bends the grid of spacetime, producing dips and distortions in the webbed fabric of the universe: the grid warps and bends, the

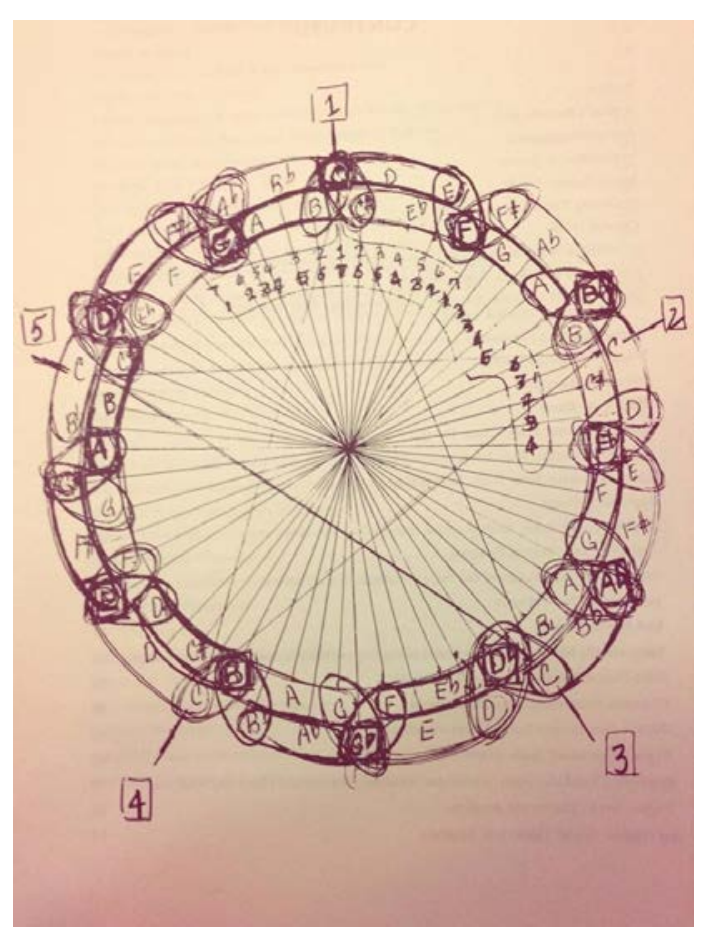

The Coltrane Circle of Fifths, from http://www.openculture.com

twisting has the effect of frame-dragging, the dilations curve timespace. Gravitational astrophysicists invite us to consider the sound of the grid when they listen to the bends of spacetime's drum. In a way, this is what Georges Bataille saw, when he suggested that "space can become a fish which eats another," because he perceives space as matter in itself, matter that also functions as a site for digesting relationships of distance (Fer 1997, 4). It is matter that inscribes the gravitational bends and the pliable planes of the polyrhythmic universe.

Reviewing grid orthodoxies invokes a commotion of disciplinary interests, definitions, and affordances (a design term for whatever an object allows a user to do). For me, the polyglot and polymathic grid has to do with ontological eurythmics. The grid's affinities are with the cult of Pythagoras, in which geometric form (and numerical elucidation, in mathematics) express the harmony of the universe. The grid's elemental lexicon is always proprioceptive. This can be articulated in architectural proportion, and in musical rhythm; in visual and sonic cultures. I don't know what is going on exactly between music and mathematics. Just don't let them tell you these things are "only" myth. 
This dispatch proceeds on the premise that the grid's dynamic pasts have something to offer to the way we think about the grid's futures (Bolter and Grusin). The grid provides points of contact (materially and metaphorically) between old and new media cultures and materialisms, from image and narrative to network. ${ }^{5}$ The return to materialism in contemporary philosophy is a manyheaded hydra and I will not attempt to account for it here. ${ }^{6}$ Except to say that it's already been around for a while; ${ }^{7}$ and that thinking the systems, organizations, materialities, and technologies of things are (alongside the social life of things, as Appadurai [1986] suggests) among the most pressing social challenges of our time.

If the grid "serves to constitute a world of objects imagined by a subject" (Siegert 2015, 107), no less anthropocentric in emphasis, in my view, is the problem of how the grid in turn facilitates the question how "power issues not simply from signification and how we signify, but also how the world of objects about us is organized" (Bryant 2011, 18). What I'm interested in are the ways that the grid, as art and science (as design), can be used to make sense of the very forces it enacts and transforms, on the understanding that cultural production cannot be separated from material registers of the real. ${ }^{8}$

For media and cultural studies, the idea is not new; for media archaeology, the emphasis on materiality and technique is all, i.e. "data storage, transmission, and calculation in technological media" (Kittler 1990, 369). In the arts, renewed attention to what materials do (human and nonhuman objects and things) gives the nod to performance theory, too (Schweitzer and Zerdy 2014). Visual cultures, in particular, sustain robust dialogues with ways of thinking objects and materials, including constructivist, geometric, and non-objective works of the most recent centuries. For the better part of this essay it is back to the future of the grid's visual cultures that I turn.

The grid's representational capabilities have long been put to use to make perspective: to emplot the heavens, hell, and empire alike (if you believe in such things). At the same time, the grid's abstractions continue to be regarded with suspicion. It's a question of legibility. The grid's Janusfaced powers compel cultural norms and refuse them. Rather than reject the grid as too distant from socially located performance research, I think we can ill afford to ignore the horizons of grid technologies and controls that so powerfully harness and transform social relationships. A return to the polymathic and polyglot grid poses an opportunity to attend both sites and modes of cultural practices and techniques. In reality, there is no choice; the grid's materialities are upon us. In the beginning was the grid, and the grid was with you.

As a whole, William Egginton's (2009) reading of the baroque could be said to locate the sum of such self-referential problematics, from idealist philosophy to discursive and object oriented works, within the anxious history of reason's durability. In baroque and neo-baroque perspectives, artifact and artifice blur the line between outsides and insides, deterritorializing agential spaces of spectacle and spectatorship. I recognize grid dynamics in these flows of thought. Read one way, the grid emplots known knowns; read another way, it supplies the circuitry of escape. But it's both at the same time, and it's never either/or. Most likely, the grid's alter ego is dark matter. 
The grid powerfully persists as organizational apparatus, or dispositive (Foucault 1980, 194). ${ }^{9}$ Mechanisms and knowledge structures operate in discursive as well as material time and space, in each case relative and dynamic, as matter still slows and bends their passages. If we are as steeped in digital architectures as we jam their floods, it is also true that "the frantic abolition of all distances brings no nearness" (Heidegger 1971, 165). Whether examined through urban grids, early modern perspectival shifts, maps, modernism, or software/hardware, treatments of the grid as a cultural technique enjoy too broad and rich a history to ignore, even if (and also because) it has been extensively studied before. Perhaps it is enough to begin by observing that city grids, for one, combine systemic and structural organizational forces and flows, at the same time that they open and are open to improvisation.

Today, the grid also has to do with the interpenetrations of old industrial grids that are linked to 'smart' grids-conjoining the likes of railroads, barbed-wire, pulp and paper manufacture, water, mining, petroleum transport, communication towers, transatlantic cables, electric information severs, nuclear reactors, satellites, digital technologies, clouds, and e-waste salvage yards (toxic dumps found in third world countries after the recycling process) to the interdependencies within and among the globe's ecologies. The digital revolution that has been the "linchpin" of global capitalism for the past thirty years, media theorists Richard Maxwell and Toby Miller (2011) argue, has a climate footprint. ${ }^{10}$ My point is uncontroversial, that in art as in science the grid is not impervious to the material world; it is made up of its diffuse parts. The grid operates interactively with a diversity of moving parts, materials, medias, and mechanics; complete with incumbent institutional and social structures, languages, logics, and algorithmic apparati.

In response to a control society that deepens the entanglements of systems, structures, and disciplines, infrastructure is today's new keyword (Berlant 2016). In early cybernetics, Norbert Weiner explains, "control is nothing but the sending of messages which effectively change the behavior of the recipient" (Weiner 1950, 8). Because so many organizational systems, structures, and disciplinary logics continually reconfigure the world (and vice-versa), today's new media cultures, materials, and ecologies are to be found wherever and however grids emplot social, visual, virtual, and spatial complexities, ad-hoc recombinatory coalitions and assemblages coding (and concealing) conduct and conflict, from public utilities to communications and cyberwarfare. As I've argued before, performance research participates in the dynamics of social change, including migrations of agency, in the material and the imaginary (Nielsen 2012).

\section{Perspective}

For most, the grid provides a gameplan: a form of organization, a mechanism, a discourse, a geometry, a city, an architecture; a media. It stipulates science, social science, and art. Easy as tictac-toe, the grid typically presents an outwardly extending logic in the ordering of things, as well as an assignment of spatial coordinates. At a glance, the grid is an apparatus to graph and make the measure of space, often to serialize it, without end. As the art critic Rosalind Krauss observes, "the grid extends, in all directions, into infinity" $(1979,60)$. Looking inwards, the grid's uses are seen too in games like checkers and chess, where laws control strategy and movement within the 
boundedness of that closed and ordered space. Closed grid schematics render fixity like the lock of a crossword puzzle. As a media, the grid grants access to "the expanded scene of viewing" (Fer 2004, 24). Behold the screen, man the scrum: vision "is not simply a matter of looking at the vista before us, but of entering into and moving across a field of vision" (57).

As seeing machine, the grid's story includes linear perspective, as in Aristotle's skenographia for the stage where it makes depth out of thin and flat spaces (Poetics, 335 BCE) and in Filippo Bruneschelli's architectural engineering where it translate three dimensional space onto two dimensional surfaces (1420). By 1435, further building on the polymathic works of Pythagoras, Euclid, Ptolomy, and Ibn al-Haytham, Leon Battista Alberti's treatises on the visible (in representational arts that include painting, architecture, and intriguingly, cryptography) begin with the mathematics of geometric form in order to put "art in the hands of the artist" (Alberti 1956, 40). Alberti understands perspective as a geometric instrument of visual representation. In the model Alberti developed for perspectival drawings, space operates as an extension of the viewer's eye, as if looking through a window. Della Pintura is a manual for producing the realistic perspectival illusions of the volumetric world, one that relies on veils, windows, mirrors, and other manner of grid mechanics, boundaries and thresholds of perception that let loose the mediations of this kinetic world. ${ }^{11}$

Scholars continue to suggest that the urban grid derives from the geometric and perspectival cultures of the Renaissance. Think Leonardo da Vinci's (1452-1519) Vitruvian Man (1490), which inscribes the mathematics of proportion in circle and square by applying architectural drafting to the technology of human form (from Vitruvius, de archetectura, 13-15 BCE). In the Codex Leicester, written in mirror-image code from right to left between 1506 and 1510 in Milan, the Tuscan again details draftings of this material world: studying hydrodynamics, deluge, and the management of water flows, for instance, in addition to the relations between suns, planets, and moons. ${ }^{12}$

Others say the great fable of Western Renaissance makes short shrift of the vast trove of thingsincluding the many cultural designs and technologies that Los Reyes Católicos in Spain made its own, before and after the Reconquista: in tiling, pottery, architecture, shipbuilding, accounting, mathematics, cartography, and finance, in addition to the patchwork of aqueducts and mills that likewise conjoin ancient Roman with Islamic and other Mediterranean material cultures and technologies; in food, dance, and song. Sometimes today's 'creativity' zeitgeist redirects curiosity about cultural forms back towards durable shells, rather than their polyphonic calls. The revolt of the medievalists urges more pluralistic views (Gersh and Roest 2003).

The visual arts have long understood the grid as a key optic of modernity that produces perception about space; orders subjects objects and things in space; at the same time that it disorganizes and disrupts matter and movement within and beyond its matrices, never attaining the fugitive and occult real. The grid's alignments are prospective and retrospective; latent and proactive; real and illusory. Interestingly, Krauss's seminal essay, "Grids," defines the grid for modern art as antimimetic, and as anti-real, concerned neither with authenticity, or the discourse of originality. 
The question, Krauss later suggests, is what emerges from the grid's repetition and recurrence $(1981,54) ;$ and from that I infer the question of how forces and systems concurrently succeed and falter in ordering the wandering matters of social life. As I noted earlier, tensions between abstraction and representation define modernist debates centering on the grid as a totalizing means of managing space through relationships of distance, on the one hand; and on the other, as the pathway to breaches in the system of modern administrations, whether in the context of pictures, or in the world.

Consistently, however, Krauss's emphasis on the grid's "paralogical suspensions," as emblem and myth, summons a structure and perhaps even more crucially a concept of the grid that allows for inconsistency, and contradiction $(1979,55)$. This insight continues to inform digital media scholarship (see Hu 2016). Given the grid's penchant for geometry, geometricisation, and fugitivity (from Star Wars to marronage), it will come as no surprise that for me, the grid's "paralogical suspensions" bring to mind things that are associated with (and given a name) in the Old and New World baroques, and the Latin American neo-baroque after that. ${ }^{13}$ The many guises of the grid's Reconquista (and runaways) never cease to churn.

On its own terms, the Latin American neo-baroque is defined not so much by the baroque's old (and rich) flamboyance, as by new world heterogeneity (and thrift)-its abundant resourcefulness, and simulacra: an avant-garde visual and literary register that accommodates many more formal and cultural logics than any one traditional 'genre' generally allows (Wollen 1993; Zamora 2006). Revisiting the Spanish baroque's profuse play with illusion and the real, the Latin American neobaroque (as an aesthetic movement) makes a power play for riotous intertextuality-heteroglossic, virtuosic, and polyrhythmic - that, like the grid, also abstains from discourses of authenticity and originality. Rather than submit to any paradigm of loss (Calabrese 1992, xii), however, I see instability, polydimensionality and change as constitutive of grid logics and systems (partners in crime), rather than outside of it.

Following Deleuze, art historian Briony Fer reminds us that the enactment of repetition itself yields difference, whether in the context of design, the technological sublime, or performance: "repetition could be partial or infinite, redemptive or destructive" $(2004,3)$. Threads of dissent, distraction and dissonance weave through every grid. Unlike some literary scholars, I don't think performance research is at risk of assuming that aesthetic forms and structures are ontologically separate from sociopolitical ones. ${ }^{14}$ I do think, however, that we cannot underestimate the surplus of systems, structures, infrastructures, and bureaucratic devices that order, thwart, and transform the materiality of social life (Nielsen forthcoming). In the brief case studies that follow, I visit two different port cities which themselves curate and review the pasts and the futures of grid logics.

\section{Bienal Internacional de Arte Contemporáneo, Cartagena de Indias, 2014}

Thanks to a friend, a conference on Negrismo (Blackness, or Négritude in the Spanish Caribbean) at the Universidad de Cartagena brought me to Colombia in the Spring of 2014. I was thinking about beisbol in the Caribbean, and the riddle of labor and performance (Nielsen, in-progress). Spanning 
high and low cultural genres, my scholarly attention to the grid is anchored in the performance arenas of sport: those carefully groomed fields of activity governed by the metricized spaces of baselines, yardlines, and sidelines-and by the simultaneously rule-abiding and errant movement, in gestures, kinetics, and kinaesthetics cojoining teams and individuals. For me, sport and dance share this fugitive shimmer, this coil of regulated and outlaw movement in the ambiguities of grid spaces, as CLR James understands it in Beyond the Boundary (1993). What I see in the baseball grid (aka the diamond) are the affordances of the grid's design, as an object of material culture, and as colonial mediascape: at once a microcosmic practice and a simulacra of urban and other grids that organize eurythmics in space and time.

But that's not what I want to talk about right now. The timing of the Negrismo conference was especially fortuitous because the first International Biennial of Contemporary Art of Cartagena de Indias was also in full swing (7 February-7 April 2014). An old city cresting the Caribbean, I was primed to 'see' Cartagena, seat of the New Kingdom of Granada (formerly Calamarí, before the Spanish arrived in 1533), in comparative cartographic perspective with other Spanish colonial grid cities in the Americas. Cartagena de Indias was an important trading port, a slave port and an administrative center. ${ }^{15}$ To this day I can't shake a rippling sense of déjà vu, accrued in that hopscotching from Carthage (Tunisia) and the Iberian Cartagena, to Cartagena, Colombia. Cities have a way of being many times and places at once; everything is in the interval.

Dispersed across a number of key historical buildings and sites so as to facilitate fluid and fresh experiences of the Centro Histórico, my first stop at the Cartagena Bienal is the Palacio de la Inquisición (Palace of the Inquisition). For the palimpsestically inclined like me, sites of exhibition matter. Los Reyes Católicos Ferdinand and Isabella established the Spanish Inquisition in 1478, which was concerned primarily with converts from Islam and Judaism. Declaring Cartagena a seat of the Inquisition in 1610 (following those in Mexico City and Lima), and adding architecture to its arsenal, Cartagena was an operating center, a node in the Spanish colonial system: to monitor and manage the colony, as well as to denounce and judge as heretics, whoever they were, and wherever they came from. ${ }^{16}$ The Palacio was completed in 1776 in baroque style, and in 1924 began to house El Museo Histórico de Cartagena de Indias.

Spanish artist Elena del Rivero's site-specific exhibition in the Palacio, ...Y tan alta vida espero... (After Santa Teresa de Jesús) (2014), is among the first publics encounter when entering the Palacio. It's about Spanish colonizers. Tucked low and almost in

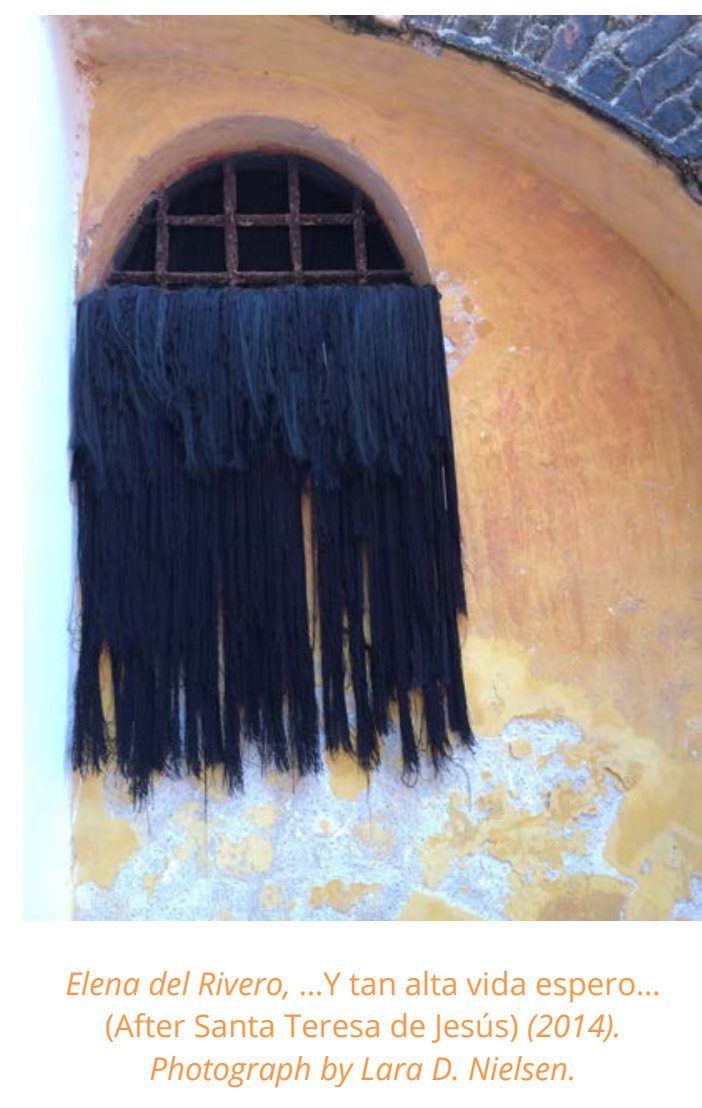


the corner of a three-story courtyard wall that directs the gaze upwards and elsewhere, the piece weaves a mass of black thread and white pearl beads through the gridiron bars of a window. At first, I thought it was hair, the needles and pins sharply tucking the absent body in. Using windows throughout the Palacio, the site-specific installation is indeed about absence: if the seat of New Granada was colonized by men from Spanish Cartagena, del Rivero infers the tactile presence of Granada women left behind in the convents of Southern Spain, whose voices are not recorded in history. The gridiron windows frame the threshold space of gendered permissions and transgressions, controlled by the iron grid at 'home' and abroad. Studying the protocols of sociability in the Palacio, del Rivero implicitly compares them with the coeval protocols of the Inquisition's tribunals and interrogations.

By presenting texture with no interior (classic modern technique), del Rivero models the violences of inquisition, itself a machine that abstracts information. The thread and the beads, in themselves imperfect replicas, perform another abstraction, by standing in for people who are made into subjects of the tribunal's endemic judgment. Del Rivero's other works focus on the kitchen as "the female grid," where stories and life gather force from a single center of strategic operation predating the ages of mechanization and industrialization. Not strictly known as a fiber artist, del Rivero's work at the Cartagena Bienal nevertheless invites visitors to think more deeply about the interlocking warp and weft of matter in Cartagena de las Indias's spacetime.

Although I come from a family of women who weave, I am told weaving has only recently been recognized as a valuable craft, "with theories of its own," let alone as a method for researching abstraction and dimensionality (Smith 2014; Porter 2014). No surprise, it is also the site of gendered divisions of labor. In her 1957 essay, "The Pliable Plane: Textiles in Architecture," Bauhaus master weaver Anni Albers writes, "When we realize that weaving is primarily a process of structural organization this thought is startling, for today thinking in terms of structure seems closer to the inclination of men than women." Nothwithstanding gendered sublations of practioner and craft, long "subordinate to form and color theory; and to the functionalist logic of architecture" (Smith 2014, xvii), weaving nevertheless has a key role to play in advancing the interpretation of grid medias.

Promoted to the status of the fiber arts after WWII, weaving tests the propensities of material in time and space. The metamorphosis of weaving harness and release the fluidities of matter; geometric patterns dissolve the grid at the same time that it reinstates it. Curating Fiber: Sculpture 1960-present, Jenelle Porter writes, “Adapting age-old techniques and traditional materials, artists working in fiber manipulate gravity, light, color, mass, and transparency to demonstrate the infinite transformations and iterations of their material." Sculptural and kinetic, in additional to rectilinear, "the opportunity of the art and craft of weaving is not the familiar tool of pictorial weaving (limited by visual or image precepts, for example in tapestries reproducing the image of paintings), but rather the architectural capacities of textile materials in weaving, prioritizing the structure of the fabric" (Smith 2014, xvii). While the diagram is the preferred instrument of architectural formalism, its bureaucratic sign; the grid's penchant for latent spatiality, however, supplies techniques for 
probing and disrupting order. In weaving, the field is sculptural and dynamic; its folds and drums sound out material culture.

Traditionally, the business of craft and the material limits of matter are one thing; the fine arts of design medias, another. As Craft theorist Glenn Adamson rhetorically asks, "Isn't craft something mastered in the hands, not the mind? Something consisting of physical actions, rather than abstract ideas?" $(2007,1)$ It's well known that the hierarchical division of labor appears in Kant's Critique of Judgment, as the subjugation of work versus the "free." "Art differs from handicraft: the first is called free, the other may be called mercenary" (Kant 1914, 184). ${ }^{17}$ Supplementing divisions of labor that so clearly reverberate in del Rivero's work-and in Cartagena, a wealthy slave port that attracted pirates and privateers (escaped slaves fled the coast city, settling inland in Palenque, meaning walled city, a city of refuge, the first free African settlement in the Americas that also uses the city grid) - what I want to follow here is the idea that weaving, like seafaring, and marronage, is a cultural technique of the grid that stalls and installs geometricization, making and escaping the system (fugitive lines).

For an installation in the Palacio de la Inquisición, this is a powerful idea. Appropriately, perhaps, it also leads to a digression (elsewhere valued as hyperlink): while visitor attention is invariably drawn to the collection of iron torture instruments assembled in the back gardens of the Palacio, 1 was more interested in the question of how, exactly, an individual might denounce an enemy to the Inquisition. Motive is easy (control, competition, sabotage), but what is the technique?

From solicitous museum guides, I gather that the living history says anonymous accusations consisted in tossing bundled and weighted paper up into one of the windows of the Palacio. Like an inbox. Not deposition (sworn out of court testimony used to gather information as part of the discovery process; in modern law, hearsay is not admissible at trial) but accusation. Judgments were orally issued from another window, on the other side of the building; the outbox. Each of these windows serves as a threshold in accounting and certification, a good reminder that for Spain the Reconquista at home, and in the New World colonization beyond, are feats of bureaucracy achieved through documents, records, licenses, petitions, certification and verification rituals that reformulated identificatory regimes of the modern age-and the arts of forgery (Siegert 2015, 82). ${ }^{18}$ In colonial mediascapes, the grid anoints institutional and other powers. A surplus of supplementarity codes the grid's pervasive geographies of reason, at the same time that its mutinous capabilities (alongside what I'm short-handing as its neo-baroque capabilities) extend well into the future of other global economic governance regimes. ${ }^{19}$

\section{Singapore National Gallery, 2016}

Extraordinary growth since the parliamentary Republic of Singapore gained independence in 1965 makes it a wealthy country of 5.7 million, with the third largest financial sector in the world, the second busiest container port, the second largest casino gambling market, and, a tax haven for the likes of Facebook cofounder Eduardo Saverin, who renounced his US passport eight months before the Facebook IPO (Tulshyan 2012). I am not a scholar of Asian languages or cultures: I went there 
for the reason many long distance travellers, and Asian talent, do: for work. I was quickly informed that because urbanization eliminated $95 \%$ of its forests, Singapore aims to be a 'smart' garden city, with $46 \%$ greenery cover by 2007 and green building standards mandating sustainability (Clifford $2015,70)$. Although the tropical skies are thick and hazy, sometimes with smoke from neighboring Indonesia, it could be far worse: increasingly, Chinese malls to the North for instance advertise the benefits of filtered (if not fresh) air, away from heavy pollution in cities like Beijing (Hornby and Zhang 2017). Spatially aware, Singapore's first Prime Minister Lee Kwan Yew (1923-2015) saw decolonization and independence through to carefully cultivated wealth: "After independence, as I searched for some dramatic way to distinguish ourselves from other Third World countries, I settled for a clean and green Singapore." ${ }^{20}$ Combining a strong city-state (that generously supports health, education, housing, the arts, and media) with globally competitive free trade polices encouraging foreign investment and tourism, Singapore recalibrates neoliberal ideologies for its own purposes with monumentalized success. ${ }^{21}$

Located in the Colonial District on St Andrews Road (another colonial grid city), the new Singapore National Gallery, which opened in November 2015, answers to that monumentality across a variety of medias, most strikingly in its architectural design. ${ }^{22}$ In the words of its promoters, the Singapore National Gallery 'occupies' two national monuments: the former Supreme Court (1939) and City Hall (the 1929 Municipal Building was renamed City Hall in 1951). "Landmarks of Singapore's colonial past and journey to independence, the buildings have borne witness to many pivotal events in the nation's history," including the inauguration of Singapore's first Head of State, Yusof Bin Ishak, in 1959; and the appointment of Singapore's first Asian Chief Justice, Wee Chong Jin, in 1963. Overlooking the Padang (the open playing fields in central Singapore, home to the Padang Cricket Ground), the Singapore National Gallery reinvents its identity as a global media city. For some, architecture has always been about creating community. An abstract idea, and a potent one, but I am told architects usually work from the abstract to the real (Holl 2013).

Escaping the rains, I paid the steep price of admission and scaled the enormous complex with plenty of time and room to wander; the spaces are so big and opulent there's hardly any opportunity for a crowd. Pausing on the upper link bridge, at the very top of the new construction, I am compelled to stop and write: This is ferociously anticolonial architecture. Then I write, This is also Singapore's enterprise architecture. By creating a canopied space between the adjacent former Court House and City Hall buildings (neoclassical structures of the West and historical landmarks)

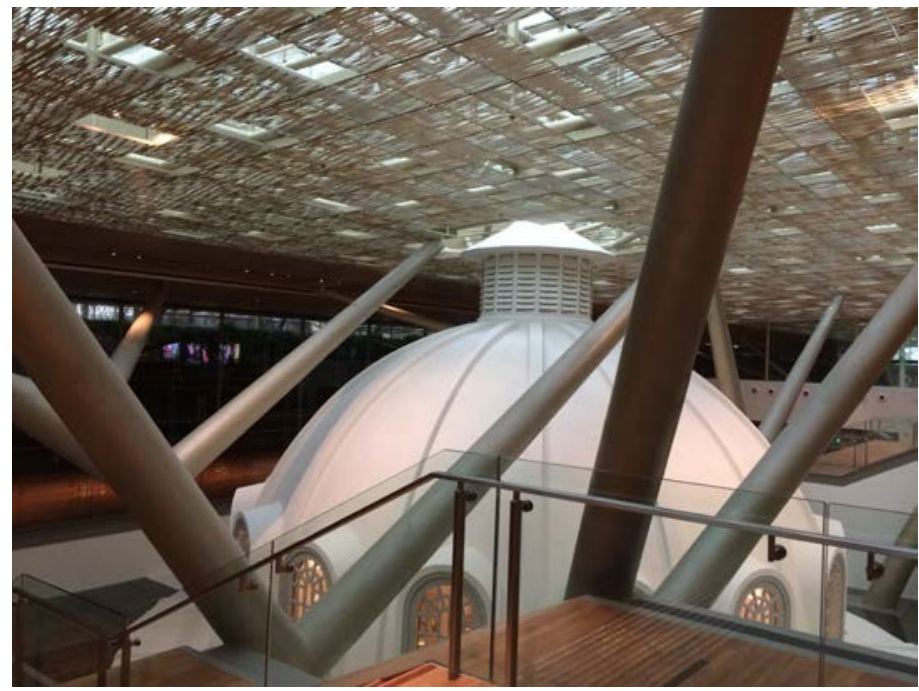

Singapore National Gallery. Photograph by Lara D. Nielsen. 
today's people now walk on air, "a civic plaza in the sky," lifted up and into a perspective that was never intended for its newly restored pillars of governance. It's great theatre: if once viewed as an architectural column to look up to, a feat of structural engineering as well as an aesthetic of power, visitors to the Singapore National Gallery are invited to respect the past at the same time that they now literally look down on its old Corinthian columns, peering into its darkened windows of authority like a oversized dollhouse that once schooled the territory. Provincializing the West, no doubt Singapore grew 'up' (Chakrabarty). Viewed from the heights of this new perspective, visitors can only regard Singapore's colonial past as the relic that it is, perhaps even sentimentally, as souvenir, recognizably handsome if quaint in its square standing. Visitors can see the rotundas of the Supreme Court right up close, sheltered from the tropical rains by a glass and metal weave above that looks and feels like a canopy.

This feeling is made possible by the aluminum tree-like support structures that organically 'grow' between the two old national monuments, intimating a living web of vertically reaching branches of such natural strength and power, such depth and reach, the networked strength of an arboreal DNA which has, evidently, so quickly overgrown the days of Raffles and the British (to say nothing of the colonial labor that was used to build them, mostly Indian) that it gives the impression that the classical architecture it straddles below and surveys abroad is simply dwarfed by the branching drives up to the platform, miniaturized just as the other colonial buildings are throughout the most of the city's corporate skyscrapers, like a cabinet of curiosities. Design theorist Manuel Lima explains, "Trees are among the earliest representations of systems of thought and been invaluable in organizing, rationalizing, and illustrating various information patterns through the ages. As the early precursors of modern-day network diagrams, tree models have been am important instrument in interpreting the evolving complexities of human understanding, from theological beliefs to the intersections of scientific subjects" $(2011,21)$. In the courthouse, rooms that once executed justice function instead as museum display, a place of memory (and its futures) now held in exhibition, stored in a treehouse; leave it to the pruning of curators.

This branchy power is big, beyond animal-making Singapore not so much a city of the lion anymore (the Merlion, in Malay, Singa-Laut), as it is an instance and an utterance of two apparently irreconcilable yet here recombinatory forces, the apex of coopetition: both centralized actual organization ("a system of strata") and virtual "rhizomatic" management. With its disarmingly familiar arboreal governmentality, presented as a cluster of upward reaching natural branches, the new construction first brings to the imagination a kind of living genealogy. For Deleuze and Guattari, of course, the verticality of the tree specifically models centralized authoritarian power, a structure with hierarchical modes of communication and preestablished paths, which they view negatively. By contrast, the rhizome, they argue, is "anti-genealogy," and even "antimemory," with lines generating spontaneous and mobile metamorphosis. At the Singapore National Gallery, this is not the contradiction it appears to be. Like Singapore's unique neoliberal assemblages, its blend of algorithmic management with strong leadership, materialize in the apertures of the Gallery. In retrospect, if they knew what we know today about trees (see Wollehben 2016) Deleuze and Guattari might not be so hard on trees. Let me explain. 
As architecture, the piece offers a monumentalized still-life-a sculpture of a thing that is indeed structured and organized, and yet also dynamic - the way an MRI (magnetic resonance imaging) captures an outwardly visible moment of form, and some of its pulsing circuitries, but cannot fully detect or display the electrical impulses within a brain, or the full extent of its radiant connectivity. Those impulses more closely resemble the kind of rhizomatic movement Deleuze and Guattari advocate, "defined solely by the circulation of states." Operating simultaneously by deep structure and by variation, "the rhizome pertains to a map that must be produced, constructed, a map that is always detachable, connectable, reversible, modifiable, and has multiple entryways and exits, and its own lines of flight" (Deleuze and Guattari 1987, 23). Three dimensionally reaching not just vertically but horizontally as well, intimating (if not achieving) the form a sphere, the Singapore National Gallery materializes as both a decentralized and a distributed network, a resilient interlocking of forms articulating macropolitics as well as the micropolitics of assemblages (25). At once an organization and a dispersal, the Singapore National Gallery proposes a neural landscape, or system: as technological mediascape, this Singapore is bigger than the old citadel of City Hall, and badder than Ayn Rand, symbols of antiquated sciences. Visitors can touch the capitol that was once capital, as if it were, yes, museum artifact.

Singapore's organic reconquest of the colonial city in favor of the once and future smart city-state, gives rise to the order of code itself, signaling not the end of time but the end of old time keeping machines and keepsakes, the age of watches, clocks, and computers replaced by digital grids, syntech, and biotic matter, assemblages of a particularly multicultural national transformation that shows no signs of losing its stride but rather capitalizes spectacularly on contradictory forces, not least Anglo-American capitalism and global algorithmic management, fine tuned with the central controls of the Southeast Asian state. Applying Nicholas Negroponte's analysis, the staging of Singapore's "clean and green" futurity at the Singapore National Gallery is on the mark. Biotech is the new digital. The materials revolution enabled by digital technology now makes it possible to program materials (to have sense, logic, and replication capacities). "Yesterday we programmed machines. Today we program matter itself" (Tibbits 2017). Game on.

That said, the architectural design is not exactly unique. The Singapore National Gallery is quite obviously two blocks conjoined by a window, an imaginary trajectory that provides a threshold and a boundary, an enclosure and aperture, an inside and an outside. As modernist fugue, the grid of windows, veils, and windows offers the space of fantasia, a projection back on the practice of perception. Reenacting the perception of form, this is a transformative strategy, describing the autotelic condition of seeing, at the same time that it facilitates a view of oneself (whether nation or city or citizen or alien) as a mediated experience, whether it is to see out of one's loneliness or to activate a commons (Olk 2014, 57). We're back in the baroque. But Kitnik (2016) also observes that today's designed open spaces and working environments articulate an ideology of flexibility, mobility, and sociability that is specific to post-Fordist creative economy production values and processes. In the networked, smartly mediated global city, developing creativity and connectedness is orthodox management strategy. 
The belief that spaces without scripted functions harbor great possibilities is nothing new to the art world, or to the grid; the question is how that belief and those grid spaces can be put to use in particular historical times and places. The history of architecture and modernism rehearses industrial progress, as Kitnick explains: "The primordial spaces of modernism were spaces of labor. It was on the industrial efficiency of the factory that many of the fundamental attributes of modern architecture-the grid, the open plan, the revealed structure-were developed" $(2016,121)$. Warehouses converted for studio and performance purposes keep the ideology of industry alive so that today, "recent architecture poses such places not as sites of class conflict or encounters with difference but simply as settings for individual interactions. In such designs, a society structured by power, class, or ideology seems hardly to exist, replaced by an idealized possibility for innovation" (122). If all the world is a grid, the Singapore National Gallery's threshold space stages the dream of cyborg subjects as unbound site of information exchange. "'Creativity' now trumps craft, and industry has given way to 'information'" (122). The grid proliferates, and accelerates.

In a 24 November 2014 speech launching Singapore's "Smart Nation," Prime Minister Lee Hsein Loong makes it clear that "The Smart Nation is not just a slogan-It is a rallying concept for all of us to work together to transform our future together." The ubiquitous connectivity of everything recharges urban grid medias in a green dream of utopic efficiency regimes; and yet nobody has to be reminded that futurism has a history. On the one hand 'technology' could theoretically facilitate the growth of ecologically sustainable cities, with progressive urban planning informed, perhaps, by the simulations of strategy game SimCity. But cities bear the scars of history, and data are a form of power (Iliadis and Russo 2016). "Smart Nation Singapore" pioneers what some critics have dubbed 'digital kampongs,' replacing local community with virtual ones powered (and monitored) by digital services. ${ }^{23}$ While grid systems like indoor plumbing, running water, and waste disposal are by now widely acknowledged as good for public health, critics worry digital connectivity could jettison urban publics like sacrificial lambs, making cities instruments of tech company trade wars. $^{24}$

But what's coming down the pike isn't just about apps and urban infrastructure as we know it. Focusing on the intersection of physical technology and analytical software to build the industrial internet (rather than all those pesky apps associated with the consumer internet of things), William Ruh, CEO of GE Digital (Boston, MA, and San Ramon, CA), says "There's going to be a shift in the universe and nobody knows how it's going to play out" (Dodge 2016). The programmability of the material world-of fluids and the entire flora and fauna of things-revives wild and far-reaching questions about the riotous presence of things. 


\section{Conclusion}

A major illusion of the art system is that art resides in specific objects.

\section{Jack Burnham $(1969,50)$}

What does the grid mean for media ecologies today? For many critics, by the late 1960s the question was no longer how words, subjects, objects, or bodies do things; it was abut how systems do things-and it was exciting. In a techno-utopianism that he would later reject, Jack Burnham's iconic 1968 and 1969 Artforum writings reach for open systems networks and communications theory to transform the possibilities of art, and the world. Burnham wrote, "We are now in transition from an object-oriented to a systems-oriented culture. Here change emanates not from things but from the way things are done" $(1968,30)$. Readers in performance theory today may find the language of dematerialized art more familiar, with its anti-modernist emphasis on what Lucy Lippard calls "the ultra-conceptual:" we know the score, the art is not what's hanging on the wall, or what's on the stage; it's what happens, it's performance (Lippard 1997). Instead, Burnham argues for the recognition of systems as media-seeing information, structure, and seriality as technologies of repetition for the polymath to engage and change those very same processes and systems. In hacker culture, information may be immaterial, but systems never exists without material support (Barbrook and Schultz 1997; Wark 2004).

In my reading, Burnham is both right and wrong. Right, because he recognizes the vitality of systems; and wrong to dismiss the vibrant matter of objects. I'll stick to our common ground. While grid cities, installations, and architectures, for instance, can be regarded as a conglomerate of arts, for Burnham they potentially make for a rich laboratory for something else: makers of aesthetic decisions, or what Burnham gives the name to the critical function of art in a technocracy, Homo Arbiter Formae. Defined in opposition to Homo Faber (the craftsman), Burnham finds prescient the economist Kenneth Galbraith's suggestion that in a technocracy, it is the control of information that matters. Because art is a form of information, a system and set of relations, and because "at a basic level artists are similar to programs... they prepare new codes and analyze data in making works of art," for Burnham art (and artists) function as a kind of double agent in the technocratic state. Burnham's double agent is a notion Claire Bishop (2008) runs with, in her critique of participatory performance regimes, focusing on artists who "engage in strategies of mediation that include delegation, re-enactment, and collaboration." 25 For Burnham, however, relationality, happenings and the like are mostly besides the point. Instead, it's about architecture, urban planning, engineering, and communications media. In the era of Homo Arbiter Formae, "Art now challenges the entire art information processing structure, not merely its content" (Burnham 1969). In short, what I gather from Burnham is that performance studies orthodoxy concerning speech acts, or how to do things with words (Austin 1962) instead finds vivid intelligibility in the material cultures and medias of grids, code, algorithmic states, and the programmability of the material world. ${ }^{26}$

What is to be done? Back at the Cartagena Bienal, at Casa 1537, Eduardo Abaroa's Proyecto de destrucción total del Museo de Antropología (2012), a fictional documentary series depicting the 
destruction of the Museo Nacional de Antropología in Mexico City (an imposingly modernist layout of concrete cubes housing collections of indigenous material cultures, built in 1964), stages a rhetorical intervention against control techniques state and non-state actors deploy (Albaraoa 2012; 2014). As Burnham's technocratic double agent, the artist explodes edifice and artifice at once. It's as striking as it is impotent, and not uncommon-making it a critical work. Staging the violence of resistance by any means, the work specifically protests collusions between the state and

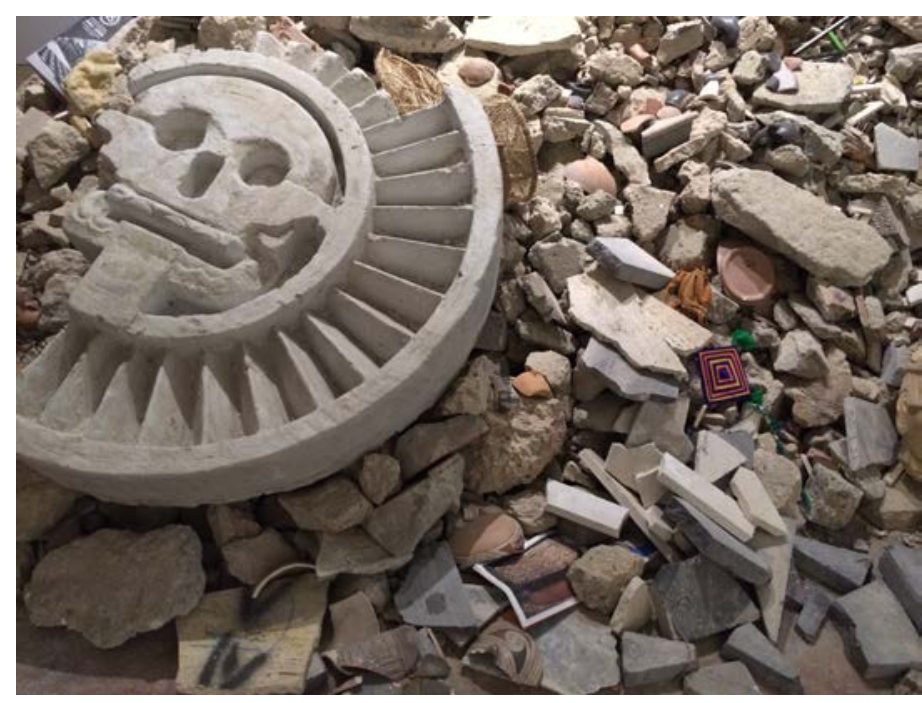

Eduardo Abaroa, Proyecto de destruccíon total del Museo de Antropología,(2012), Cartagena. Photograph by Lara D. Nielsen.

anthropology. ${ }^{27}$ In the context of the Biennial industry, however, the recuperation of state sponsored cultural patrimony is rehabilitated in the name of those very lines of flight that both escape and fundamentally constitute control regimes.

While the kinks and flows of grid architectonics articulate capacious dynamics, the question of how to do things with the grid (and vice versa: how things are using the grid) revives urgent questions of power and migrations of agency. My approach to the grid seeks to open familiar dialogues, about variants of subjectivity and presence, to the materialities and devices of systems, structures, infrastructures, communications technologies, administrations, bureaucratic operations, and biotics. This is to expand and shift attention from the representation of meaning to the conditions of representation; in so doing, the grid offers ways to examine the rigs of repetition, material and otherwise. Whereas closed grid regimes render fixity like the lock of a crossword puzzle, they also suggest the universe is both more capaciously diverse, and, in a state of flux. To riff off László Moholy-Nagy, the illiteracy of the future will be ignorance not of reading, writing, or even photography, but of the grid and its networks $(1989,90)$. The observation is not necessarily apocalyptic (in conservative arts and humanities terms), if we take the grid for all it's worth: an equivocal surplus of literacy in agential moves for this kinetic world. 
${ }^{1}$ Media archaeology, following Foucault, aims not for linear progression but "tries to establish the systems of transformation that constitute change" (Foucault 1972, 173). Jussi Parikka explains: "Where do you start when you begin thinking media archaeologically? Do you start with past media, like a 'proper' historian? Or from our own current world of media devices, software, platforms, networks, social media, plasma screens and such, like a 'proper' analyst of digital culture would? [...] you start in the middle - from the entanglement of past and present, and accept the complexity this decision brings with it to any analysis of modern media culture" $(2012 a, 5)$.

${ }^{2}$ A principle of connectivity in graph theory, Menger's Theorem indentifies flow and optimization problems in networks, necessary for building and sustaining an equilibrium of inputs and outputs in distributive systems.

3 The intimacy between maps and paintings is well-known.

\begin{abstract}
Until science claimed cartography, mapmaking and landscape painting were kindred activities, often performed by the same hand. [...] Cartography and landscape painting were also connected by the fact that their practitioners held common conceptions of the earth and shared the problems of selecting phenomena and of representing them coherently on a plane surface. [...] So alike were the approaches and the products of painters and cartographers that until the Renaissance there was no terminology to distinguish clearly between maps and paintings. (Rees 1980, 72).
\end{abstract}

${ }^{4}$ See Lippard (1972). Fluxus art historian Hannah Higgins remarks, "Looking at the geometric abstraction, musical notation, choreography and performance formats of the 1950 s and 60s, I saw grids everywhere" $(2009,8)$.

${ }^{5}$ I should declare my view, elaborated elsewhere, that performance is a media and that the body in performance, should it continue to retain center stage in the field, is always a remediated entity (Nielsen 2014; forthcoming). The return to media archaeology suggests a handy pointer: "Media are spaces of action for constructed attempts to connect what is separated" (Zielinksi 2006, 7). In Jussi Parrika's rejoinder, "media archaeology has historically resided in between academic departments (media studies, media arts, film studies, history) and arts institutions and practices" $(2012,15)$.

${ }^{6}$ These days, new approaches to materialism and realism tend to challenge discursive methods of analysis by positing a realism independent of human beliefs and desires, and a materialism constituted purely in terms of physical processes and matter, raising big questions about "thing power," citizenship, spectatorship, witness, authorship, and representation. Sometimes they tend towards an analysis of value that does not center on capital. See Bennett (2010); Harman (2010); Parikka (2012b); Cox, Jaskey and Malik (2015); Harvey et al. (2014); Tompkins (2016).

${ }^{7}$ Deleuze and Guattari (1987); Bergson (1990); Haraway (1991); Grosz (1998); Iliadis and Russo (2016).

${ }^{8}$ Elizabeth Grosz suggests philosophy, as art's "wayward twin," has a place in assessing the same "provocations and incitements to creation" usually associated with art critiques of signification and subjectification (1998, 2).

${ }^{9}$ Michel Foucault explains, "What I'm trying to pick out with this term is, firstly, a thoroughly heterogeneous ensemble consisting of discourses, institutions, architectural forms, regulatory decisions, laws, administrative measures, scientific statements, philosophical, moral and philanthropic propositions-in short, the said as much as the unsaid. Such are the elements of the apparatus. The apparatus itself is the system of relations that can be established between these elements" (1980,194).

10 While the 'clean industry myth' persists, the problem of planned obsolescence connected to e-waste have only recently been included in operations and supply chain management literatures. Richard Maxwell and Toby Miller explain that the digital media are "participants in climate change, pollution, declining biodiversity, and habitat decimation-four constituents of the global ecological crisis" (2011, 468-69). On garbage economies, see Nielsen 2002.

11 Today's ways of seeing (with apologies to John Berger) include, for instance, radiology, as imaging technologies proliferate the arts and sciences. Contra Walter Benjamin (or readings of Benjamin), perhaps it is all for the better, 
but then maybe Benjamin wasn't so much against the copy per se but attuned to the transformational properties of mechanical reproduction technologies heading our way. As multimedia artist William Kentridge remarks, "I'm interested in machines that tell you what it is to look, that make you aware of the process of seeing, make you aware of what you do when you construct the world by looking at it" (2016).

12 Vetruvius was a Roman architect and a military engineer. I saw curated excerpts of the notebooks on display at a Minneapolis Institute of Arts exhibit, Leonardo da Vinci, the 'Codex Leicester,' and the Creative Mind (2015). Da Vinci's documented fusions of art, engineering, and military design was purchased by Bill Gates for $\$ 30.8$ million in 1994 (according to https://new.artsmia.org/press/leonardo-da-vincis-codex-leicester-on-view-at-mia/). An earlier exhibit I saw, the New York Metropolitan Museum of Art's 2003 Leonardo da Vinci: Master Draftsman, is much more forthcoming about da Vinci's penchant for war technologies, even though he hated war: he drew and designed tanks, cannons, crossbows, clubs, and explosives, rendering soldiers felled in violent battle. See also the drawings in Nicolas Macchivelli's 1521 Arte de la Guerra (The Art of War).

13 It has to be said, though, that those paralogical suspensions Krauss speaks of involve things that are not limited to periodization, or even to those genres. This reading is uncontroversial: there have been a number of 'liberators' of artistic form from chronological confines (Focillon 1989), not least concerning the time-tripping baroque (Maravall 1986; Deleuze 1993; Ndalianis 2004). For Egginton, "The Baroque is theater, and the theater is baroque" (2009, 39).

${ }^{14}$ Caroline Levine invites readers to export literary analysis to "new objects," such as "the social structures and institutions that are among the most crucial sites of political efficacy" $(2015,23)$.

${ }^{15}$ While Pre-Colombian peoples lived there before the founding of the city in 1533, the city's Spanish name comes from the Southeast Spanish city of Cartagena (or Al-Qartäjanna in Arabic), which was named after Carthage in Tunisia (once one of the largest cities of the Hellenic Mediterranean), by the Carthaginian governor of Iberia, Hasdrubal the Fair-brother in-law to none other than the renowned military strategist, Hannibal (247-183 BCE). Cartagena was an important trading port, a slave port and an administrative center.

${ }^{16}$ The mission of the Museo Histórico de Cartagena de las Indias is to educate publics through the collection and exhibition of objects of material culture for display, and the site is itself a medium, mechanism, and an object of study.

17 While it is not uncomplicated, when Adolph Loos describes handicraft as corresponding to femininity and degeneracy, in Ornament and Crime (1910), he adapts this hierarchy for the purposes of repudiating the unfreedoms of unwaged domestic labor in the age of industrial waged labor.

18 In Spain today, that bureaucracy of authentication and accreditation is alive and well, where the idea of the original document, the signature, and the seal still count for something (when so often digital technologies makes the hand redundant). See Siegert (2015); Cohen and Glover (2014); Nielsen (forthcoming).

19 This play between movements on and off the record of the grid, from accusation to announcement, from oral to written deed, from street to office, again reminds me of something. The evangelizing work of Spanish Franciscan Fray Bernardino de Sahagun's 1577 La Historia Universal de las Cosas de Nueva España (Universal History of the Things of New Spain) - aka the Florentine Codex -arranges a codex (book form) of texts and illustrations that seek to translate Coatepec Nahuatl linguistic practices and the cosmological beliefs of Mexico's New World, into Spanish. The encyclopedic 'record,' a document produced under duress of conquest, derived from a diversity of oral interlocutors employed to transfer information into pictorial and written forms.

20 See Yew (2000). The Prime Minister's words are on public display near the Paranakan Museum. The Peranaken Museum collects arts and artifacts of hearth and home: "In Malay, Peranaken means 'child of' or 'born of' and is used to refer to people of mixed ethnic origins. Chinese Peranakens are the majority, but there are also Peranaken communities of other ethnicities in Southeast Asia, including Arab, Indian, and Eurasian."

${ }^{21}$ In its first floor permanent exhibits, "The Singapore History Gallery" and "We Built a Nation," The National Museum of Singapore narrates the city-state's changes over time, from $14^{\text {th }}$ century port to Singapura, Crown 
Colony (1867), British surrender to Japanese occupation in 1942, the self government of and today's global city, with over 7,000 multinational corporations and astonishing growth rates. With four official languages (English, Malay, Mandarin Chinese, and Tamil), many more linguistic expat and immigrant communities (including Nokia's Finns and Norwegians), and a swelling of arts and cultural institutions that make it a global hub by any quantifying measure, the five stars on Singapore's flag signify the city state's official values of Peace, Justice, Equality, Democracy, and Progress.

22 Designed by Studio Milou Architecture from France in collaboration with CPG Consultants Pte Ltd.

23 "Information and Communication Technologies (ICTS) include radio, television, cellular phones, computer and network hardware and software, satellite systems, as well as services and applications associated with them. According to the European Commission, the importance of ICTs lies less in the technology itself than in its ability to create greater access to information and communication in underserved populations," prompting attention to the digital divide, and ICT for development (http://searchcio.techtarget.com/definition/ICT-information-andcommunications-technology-or-technologies).

24 See Townsend (2013). With many smart ideas, one smart nation, and plenty of trisectoral collaboration, electronic networks, sensors, and apps proliferate the digital service economy, amass the internet of things, build the industrial internet of things - and reconfigure civil society. In the public, digital applications and platforms manage not just buses, trains, planes, automobiles, hospitals, and banks but systems of transportation, health, food, and financial services industries.

25 Bishop hews closely to analyzing modes of subjectification that the rejection of objects (and objectivity) characteristically entails. See Claire Bishop $(2008,111)$.

26 In cyberwarfare, the 2010 detection of Stuxnet, a self-replicating computer malware capable of autonomous crossings between the virtual and this kinetic world, alerts publics to the reach of algorithmic grid medias. See Gibney (2016).

${ }^{27}$ Abaroa's project speaks to continuity and change in curatorial practices and/as governance. Critics similarly concerned with the role of anthropology in the coloniality of power increasingly reevaluate the regimes that usually inform curatorial authority. For example, Tony Bennett, Ben Dibley and Rodney Harrison express "a concern with the ways the processes of data collection and modes of anthropological expertise on which they are dependent are enrolled in various governmental practices targeting the conduct of colonial and metropolitan populations and subjects" $(2014,145)$. Their focus is on the assemblages of material culture (including "the human bodies, recording devices, paper techniques, theoretical statements and so on"), which make anthropological data calculable, [as?] in "the museum collection, the photographic archive, the population census, the social survey or the anthropologist's office" (140). In Bennett's terms, such fieldwork agencements doubly operate as assemblages at the intersections of museums, fields, publics, universities: all the administrative practices and networks of the research enterprise (142).

\section{Works Cited}

Abaroa. Eduardo. 2012. Proyecto de destrucción total del Museo de Antropología [exhibition]. 7 February-7 April 2014. Cartagena de las Indias, Colombia: Bienal Internacional de Arte Contemporáneo.

2014. "Notes to a Project: Total Destruction of the Anthropology Museum." Scapegoat: Landscape/Architecture/Political Economy 6 ("Mexico DF/NAFTA"): 147-151.

Adamson, Glenn. 2010. The Craft Reader. London: Bloomsbury.

Adorno, Theodor. 2005. Minima Moralia: Reflections from Damaged Life. Translated by E. F. N. Jephcott. London, verso.

Albers, Anni. 1957. "The Pliable Plane: Textiles in Architecture." Accessed April 2015. http://www.albersfoundation.org/teaching/anni-albers/ 
Alberti, Leon Battista. (1435-46) 1956. "Prologue." Translated by John R. Spencer. In On Painting, 39-42. New Haven: Yale University Press.

Appadurai, Arjun. 1986. "Introduction: Commodities and the Politics of Value." In The Social Life of Things: Commodities in Cultural Perspective, edited by Arjun Appadurai, 3-63. Cambridge: Cambridge University Press. https://doi.org/10.1017/CBO9780511819582.003

Aristotle. 1998. Poetics. Chicago: University of Chicago Press.

Austin, J.L. 1962. How to Do Things with Words. The William James Lectures Delivered at Harvard University in 1955. Boston: Clarendon.

Barbrook, Richard, and Pit Schultz. 1997. "The Digital Artisans Manifesto." Accessed 12 October 2016. http://www.imaginaryfutures.net/2007/04/16/the-digital-artisans-manifesto-by-richard-barbrook-andpit-schultzl

Bataille, Georges. 1930. "Space." Documents 1.

Benjamin, Walter. (1935) 1970. "The Work of Art in the Age of Mechanical Reproduction." In Illuminations, edited by Hannah Arendt, translated by Harry Zohn, 219-53. London: Cape.

Bennett, Jane. 2010. Vibrant Matter: A Political Ecology of Things. Durham, NC: Duke University Press.

Bennett, Tony, Ben Dibley, and Rodney Harrison. 2014. "Introduction: Anthropology, Collecting and Colonial Governmentalities." History and Anthropology 25 (2): 137-149. https://doi.org/10.1080/02757206.2014.882838

Bergson, Henri. 1990. Matter and Memory. Translated by W. Scott Palmer and Nancy Margaret Paul. New York: Zone Books.

Berlant, Lauren. 2016. "The Commons: Infrastructures for Troubling Times." Environment and Planning D: Society and Space 34 (3): 393-419. https://doi.org/10.1177/0263775816645989

Bhabha, Homi. 1984. "Of Mimicry and Man: The Ambivalence of Colonial Discourse." October 28: 125-133.

Bishop, Claire, and Mark Sladen. 2008. Double Agent: Pawe Althamer/Nowolipie Group, Phil Collins, Dora García, Christoph Schlingensief, Barbara Visser, Donelle Woolford, Artur Zmijewski [Exhibition]. February 14-April 6. London: Institute of Contemporary Arts.

Bolter, Jay David, and Richard Grusin. 2003. Remediation: Understanding New Media. Cambridge, MA: MIT Press.

Bryant, Levi. 2011. The Democracy of Objects. Ann Arbor, MI: University of Michigan/Open Humanities Press. https://doi.org/10.3998/ohp.9750134.0001.001

Bryant, Levi, and Nick Srnicek, Graham Harman. 2011. The Speculative Turn: Continental Materialism and Realism. Melbourne: re.press.

Burnham, Jack. 1968. "Systems esthetics." Artforum 7 (1): 30-35.

1969. "Real time systems." Artforum 8 (1): 49-55.

Calabrese, Omar. 1992. Neo-Baroque: A Sign of the Times. Princeton: Princeton University Press.

Césaire, Aimé. (1955) 2000. Discourse on Colonialism. New York: New York University Press.

Chakrabarty, Dipesh. 2009. Provincializing Europe: Postcolonial Thought and Historical Difference. Princeton: Princeton University Press.

Clifford, Mark. 2015. The Greening of Asia: The Business Case for Solving Asia's Environmental Emergency. New York: Columbia Business School Publishing.

Cohen, Matt and Jeffrey Glover. 2014. Colonial Mediascapes: Sensory Worlds of the Early Americas. Lincoln: University of Nebraska Press.

Cox, Christoph and Jenny Jaskey and Suhail Malik. 2015. Realism Materialism Art. Annandale-on- Hudson, NY / Berlin: Center for Curatorial Studies, Bard College / Sternberg Press. 
Deleuze, Gilles. 1993. The Fold: Leibniz and the Baroque. Translated by Tom Conley. Minneapolis: University of Minnesota Press.

Deleuze, Gilles and Felix Guattari. 1987. A Thousand Plateaus: Capitalism and Schizophrenia. Translation and forward by Brian Massumi. Minneapolis: University of Minnesota Press.

Dodge, John. 2016. "GE focusing on planes, trains, and ... software," Boston Globe, 24 January. https://www.bostonglobe.com/business/2016/01/24/focusing-planes-trains-and-software/

Egginton, William. 2009. The Theater of Truth: The Ideology of (Neo) Baroque Aesthetics. Palo Alto: Stanford University Press. https://doi.org/10.11126/stanford/9780804769549.001.0001

Fer, Briony. 1997. On Abstract Art. New Haven: Yale University Press.

___. 2004. The Infinite Line: Re-making Art After Modernism. New Haven: Yale University Press.

Focillon, Henri. 1989. The Life of Forms in Art. New York: Zone Books.

Foucault, Michel. 1972. The Archaeology of Knowledge and The Discourse on Language. Translated by A.M. Sheridan Smith. New York: Pantheon.

_-_. 1980. Power/Knowledge: Selected Interviews and Other Writings, 1972-1977. Translated by Colin Gordon, Leo Marshall, John Mepham, and Kate Soper. New York: Pantheon.

Gersh, Stephen, and Bert Roest, eds. 2003. Medieval and Renaissance Humanism: Rhetoric, Representation and Reform, 115. Leiden and Boston: Brill's Studies in Intellectual History.

Gibney, Alex. 2016. Zero Days. Magnolia Pictures.

Glissant, Édouard. 1990. Poetics of Relation. Ann Arbor: University of Michigan Press.

Grosz, Elizabeth. 1998. Chaos, Territory, Art: Deleuze and the Framing of the Earth. New York: Columbia University Press.

Haraway, Donna. 1991. Simians, Cyborgs, and Women: The Reinvention of Nature. New York: Routledge.

Harman, Graham. 2010. Toward Speculative Realism: Essays and Lectures. New York: Zero Books.

Harvey, Penny, et al, eds. 2014. Objects and Materials: A Routledge Companion. New York: Routledge.

Heidegger, Martin. 1971. "The Thing." Translated by Albert Hofstadter. In Poetry, Language, Thought, 161-184. New York: Harper and Row.

Higgins, Hannah. 2009. The Grid Book. Cambridge, MA: MIT Press.

Holl, Stephen. 2013. "What is Architecture? (Art)?" The Brooklyn Rail, 4 September. Accessed 2 November 2016. http://www.brooklynrail.org/2013/09/criticspage/what-is-architecture-art

Hollander, Roel. 2017. "John Coltrane's Tone Circle." Accessed April 1. https://roelhollander.eu/en/blogsaxophone/Coltrane-Tone-Circle/

Hornby, Lucy, and Archie Zhang. 2017. "Beijing malls compete on clean air credentials." Financial Times, 6 January. https://www.ft.com/content/e25219d8-d3a9-11e6-9341-7393bb2e1b51

Hu, Tung-Hui. 2016. A Prehistory of the Cloud. Cambridge, MA: MIT Press.

Iliadis, Andrew and Frederica Russo. 2016. "Critical Data Studies: An Introduction." Big Data \& Society, JulyDecember: 1-7. https://doi.org/10.1177/2053951716674238

James, C.L.R. 1993. Beyond A Boundary. Durham: Duke University Press.

Kant, Immanuel. 1914. The Critique of Judgement: Kant's 1914 English Edition (Illustrated). Accessed 20 November, 2016. http://www.wealthofnation.com

Kentridge, William. 2016. Interview. In Terms of Performance. Accessed 2 December 2016. http://intermsofperformance.site/interviews/william-kentridge 
Kitnick, Alex. 2016. "GIANT STEPS: Alex Kitnick on the staircase in contemporary architecture." Artforum International 55 (3): 121-122.

Kittler, Friedrich. 1992. Discourse Networks. Palo Alto: Stanford University Press.

1999. Gramophone, Film, Typewriter. Palo Alto: Stanford University Press.

Kittler, Friedrich and John Johnston. 1997. Literature, Media, Information Systems. Amsterdam: Gordon \& Breach.

Krauss, Rosalind. 1979. "Grids." October 9: 51-64.

1981. "The Originality of the Avant-garde: A Postmodernist Repetition." October 18: 47-66.

Lefebvre, Henri. 2007. The Production of Space. Malden, MA: Blackwell.

Levine, Caroline. 2015. Forms: Whole, Rhythm, Hierarchy, Network. Princeton: Princeton University Press. https://doi.org/10.1515/9781400852604

Lima, Manuel. 2011. Visual Complexity: Mapping Patterns of Information. New York: Princeton Architectural Press.

Lippard, Lucy. 1972. Grids grids grids grids grids grids grids grids [exhibition]. January 27-March 1. Philadelphia: Institute of Contemporary Art, University of Pennsylvania.

_-_. 1997. Six Years: The Dematerialization of the Art Object from 1966 to 1972. Berkeley: University of California Press.

Lohr, Steve. 2016. "G.E., the 124-Year-Old Software Start-Up," The New York Times, 27 August. https://www.nytimes.com/2016/08/28/technology/ge-the-124-year-old-software-start-up.html

Loong, Lee Hsien. 2014. "Why Smart Nation: Our Vision." 24 November. Accessed May 2015. https://www.smartnation.sg/happenings/speeches/smartnationlaunch\#sthash.Q8EpZ4NF.dpuf

Loos, Alfred. (1910) 2003. "Ornament and Crime." In The Industrial Design Reader, edited by Carma Gorman, 74-81. New York: Allworth.

Maravall, José Antonio. 1986. Culture of the Baroque: Analysis of a Historical Structure. Manchester: Manchester University Press.

Maxwell, Richard, and Toby Miller. 2011. "The Environment and Global Media Communication Policy." In The Handbook of Global Media and Communication Policy, edited by Robin Mansell and Marc Raboy, 467-485. Malden: Blackwell. https://doi.org/10.1002/9781444395433.ch29

The Metropolitan Museum of Art. 2003. Leonardo da Vinci, Master Draftsman. 22 January-30 March, New York. http://www. metmuseum.org/press/exhibitions/2002/leonardo-da-vinci-master-draftsman-opens-atmetropolitan-museum-january-22

Mignolo, Walter. 1995. The Darker Side of the Renaissance: Literacy, Territoriality, Colonization. Ann Arbor: University of Michigan Press.

Moholy-Nagy, László. 1989. "Photography and Advertising." In Photography in the Modern Era: European Documents and Critical Writings, 1913-1940, edited by Christopher Phillips, 82-89. New York: Aperture.

Mwamba, Corey. "Coltrane's Way of Seeing." Accessed April 2017. http://www.coreymwamba.co.uk/

Ndlianis, Angela. 2004. Neo-Baroque Aesthetics and Contemporary Art. Cambridge: MIT Press.

Negroponte, Nicholas. 1995. Being Digital. New York: Alfred A. Knopf.

Nielsen, Lara D. 2002. "Garbage, Gone." Women \& Performance: A Journal of Feminist Theory 24: 105-131. https://doi.org/10.1080/07407700208571373

2014. "So Close to Burning: Intermedia and Documentary." Text and Performance Quarterly 34 (3): 286-303. https://doi.org/10.1080/10462937.2014.913808

Forthcoming. "Freedom With Silence: Cryptoanalytics and the Differend in the Afterlives of Legal Things." In Law and/as Performance, edited by Austin Sarat and Martha Umphrey. Amherst: University of Massachusetts Press. 
___. In-progress. The Riddle of Labor and Performance.

Nielsen, Lara D., and Patricia Ybarra. 2012. Neoliberalism and Global Theatres: Performance Permutations. Basingstoke: Palgrave Macmillan. https://doi.org/10.1057/9781137035608

Olk, Claudia. 2014. Virginia Woolf and the Aesthetics of Vision. Anglia Book Series 45. Berlin/Boston: Walter de Gruyter $\mathrm{GmbH} \&$ Co KG.

Parikka, Jussi. 2012a. What is Media Archaeology? Cambridge: Polity.

2012b. "New Materialism as Media Theory: Medianatures and Dirty Matter." Communication and Critical/Cultural Studies 9 (1): 95-100. https://doi.org/10.1080/14791420.2011.626252

Porter, Janelle. 2014. Fiber: Sculpture 1960-Present. Boston: Prestel.

Powell, A.K. 2012. Depositions: Scenes from the Late Medieval Church and the Modern Museum. New York: Zone Books.

Rees, Ronald. 1980. "Historical Links between Cartography and Art." Geographical Review 70 (1): 60-78. https://doi.org/10.2307/214368

Roberts, Neil. 2015. Freedom as Marronage. Chicago: University of Chicago Press.

del Rivero, Elena. 2014. ... tan alta vida espero... (After Santa Teresa de Jesús) [exhibition]. 7 February-7 April. Cartagena de Indias, Colombia: Bienal Internacional de Arte Contemporáneo.

de Sahagún, Bernardo. 1499. Historia general de las cosas de Nueva España / General History of the Things in New Spain. Accessed January 2015. https://www.wdl.org/en/item/10096/

Schweitzer, Marlis, and Joanne Zerdy. 2014. Performing Objects and Theatrical Things. Basingstoke: Palgrave Macmillan. https://doi.org/10.1057/9781137402455

Siegert, Bernhard. 2015. Cultural Techniques: Grids, Filters, Doors and Other Articulations of the Real. New York: Fordham University Press. https://doi.org/10.5422/fordham/9780823263752.001.0001

Smith, Tiai. 2014. Bauhaus Weaving Theory. Minneapolis: University of Minnesota Press. https://doi.org/10.5749/minnesota/9780816687237.001.0001

Sutton, Daud. 2007. Islamic Design: A Genius for Geometry. Glastonbury: Wooden Books.

Tibbits, Skylar. 2017. "Programmable." Paper presented at Being Material, MIT Media Lab, Cambridge, MA, 22 April.

Tompkins, Kyla Wazana. 2016. "On The Limits and Promise of New Materialist Philosophy." Lateral: Journal of the Cultural Studies Association 5 (1). https://doi.org/10.25158/L5.1.8

Townsend, Antony M. 2013. Big Data, Civic Hackers, and the Quest for a New Utopia. New York: W.W. Norton \& Company.

Tulshyan, Ruchika. 2012. "Why Eduardo Saverin Moved to Singapore." Forbes, 11 May.

Wark, McKenzie. 2004. A Hacker Manifesto. Cambridge, MA: Harvard University Press.

Weiner, Norbert. 1950. The Human Use of the Human Being. Cambridge, MA: Riverside Press.

Wollen, Peter. 1993. "Baroque and Neo-Baroque in the Age of Spectacle." Point of Contact 3 (3): 9-21.

Wollheben, Peter. 2016. The Secret Life of Trees: What They Feel, How They Communicate-Discoveries from a Secret World. Translated by Jane Billinghurst. Vancouver: Greystone Books.

Yew, Lee Kwan. 2000. From Third World to First: The Singapore Story, 1965-2000. New York: Harper.

Zamora, Lois Parkinson. 2006. The Inordinate Eye: New World Baroque and Latin American Fiction. Chicago: University of Chicago Press.

Zielinski, Siegfried. 2006. Deep Time of the Media: Toward an archaeology of hearing and seeing by technical means. Cambridge, MA: MIT Press. 


\section{Biography}

Writer and Professor Associado Lara D. Nielsen works with transnational arts, medias, and economies. Recent published works can be found in Law and/as Performance; Scapegoat: Architecture/Landscape/Political Economy; and Text \& Performance Quarterly. Nielsen's first collaborative book project, Neoliberalism and Global Theatres (2012) studies complex relationships between the arts and free markets, globally.

(C) 2017 Lara D. Nielsen

cc (i) (2) Except where otherwise noted, this work is licensed under a Creative Commons Attribution-

cc. 